\title{
Ventilator touchscreen as source of ESBL- producing Klebsiella pneumoniae outbreak
}

\author{
A Narciso $^{1 *}$, L Gonçalves $^{2}$, A Costa $^{2}$, A Godinho $^{2}$, F Fernandes $^{2}$, A Duarte $^{1}$ \\ From International Conference on Prevention \& Infection Control (ICPIC 2011) \\ Geneva, Switzerland. 29 June - 2 July 2011
}

\section{Introduction / objectives}

Klebsiella pneumoniae strains producing extended-spectrum $\beta$-lactamases(ESBLs) are a major problem in many different hospitals worldwide,causing outbreaks.

\section{Methods}

An outbreak of ESBL-producing $K$. pneumoniae occurred from 17 August to 28 December 2009 in a acute care hospital, Lisboa. Four patients in intensive care unit were infected or colonized and strains were isolated predominantly from blood and catheter. All infections or colonization were nosocomially acquired, with the patients having been hospitalized from 11 to100 days prior to isolation of the organism. A descriptive and prospective surveillance was performed to control the outbreak and environmental investigations were carried out to identify the source, mainly on equipment for monitorization and medical support.

\section{Results}

Eighteen $K$. pneumoniae strains were identified from patients: seven and nine strains from clinical and screening specimens respectively; and two strains from ventilator touchscreen and suction device manometer. M13 fingerprint analysis revealed closely related strains confirmed by MLST (ST15) performed in selected strains. All of the K. pneumoniae isolates had the same pattern of multiresistance.Molecular experiments revealed that CTX-M-15and SHV-28 were the prevalentESBLs. The outbreak was controlled and eliminated by a combination of intensive infection control measures and rigorous local surveillance. These safeguards remain in place and no outbreaks were detected since January 2010.

${ }^{1}$ iMed.UL, Faculdade de Farmàcia, Portugal

Full list of author information is available at the end of the article

\section{Conclusion}

To our knowledge, this is the first reported hospital outbreak that provides evidence that the ventilator touchscreen can be a transmission vector for ESBL $K$. pneumoniae isolates.

\section{Disclosure of interest}

None declared.

\section{Author details}

${ }^{1}$ iMed.UL, Faculdade de Farmàcia, Portugal. ${ }^{2}$ SAMS Hospital, Lisboa, Portugal.

Published: 29 June 2011

doi:10.1186/1753-6561-5-S6-078

Cite this article as: Narciso et al:: Ventilator touchscreen as source of ESBL-producing Klebsiella pneumoniae outbreak. BMC Proceedings 20115 (Suppl 6):O78.
Submit your next manuscript to BioMed Central and take full advantage of:

- Convenient online submission

- Thorough peer review

- No space constraints or color figure charges

- Immediate publication on acceptance

- Inclusion in PubMed, CAS, Scopus and Google Scholar

- Research which is freely available for redistribution

Submit your manuscript at www.biomedcentral.com/submit
C Biomed Central

\section{Biomed Central}

(c) 2011 Narciso et al; licensee BioMed Central Ltd. This is an open access article distributed under the terms of the Creative Commons Attribution License (http://creativecommons.org/licenses/by/2.0), which permits unrestricted use, distribution, and reproduction in any medium, provided the original work is properly cited. 